\title{
PREVALENCE OF DIABETES MELLITUS AND IMPAIRED GLUCOSE TOLERANCE IN PATIENTS WITH DECOMPENSATED CIRRHOSIS BEING EVALUATED FOR LIVER TRANSPLANTATION: the utility of oral glucose tolerance test
}

\author{
Ana Carolina Costa BRAGANÇA ${ }^{1}$ and Mário Reis ÁLVARES-da-SILVA²
}

\begin{abstract}
Context - Cirrhosis, diabetes mellitus, impaired glucose tolerance, insulin resistance, and protein calorie malnutrition are important issues in cirrhotic patients because they can increase the progression of liver disease and worsen its prognosis. Objective - To determine the prevalence of diabetes mellitus, impaired glucose tolerance and insulin resistance in cirrhotic patients being evaluated for liver transplantation and their impacts on a 3-month follow-up, and to compare fasting glycemia and oral glucose tolerance test. Methods - A cross-sectional study was performed in consecutively included adult patients. Diabetes mellitus was established through fasting glycemia and oral glucose tolerance test in diagnosing diabetes mellitus in this population. HOMA-IR and HOMA- $\beta$ indexes were calculated, and nutritional assessment was performed by subjective global assessment, anthropometry and handgrip strength through dynamometry. Results - Diabetes mellitus was found in 40 patients $(64.5 \%), 9(22.5 \%)$ of them by fasting glycemia and 31 $(77.5 \%)$ of them by oral glucose tolerance test. Insulin resistance was found in $40(69 \%)$ of the patients. There was no relationship between diabetes mellitus and the etiology of cirrhosis. Protein calorie malnutrition was diagnosed in a range from $3.22 \%$ to $45.2 \%$ by anthropometry, $58.1 \%$ by subjective global assessment and $88.7 \%$ by handgrip strength. Diabetes mellitus identified by oral glucose tolerance test was related significantly to a higher prevalence of infectious complications and deaths in a 3-month period $(P=0.017)$. Conclusion - The prevalence of diabetes mellitus, impaired glucose tolerance, insulin resistance and protein calorie malnutrition is high in cirrhotic patients on the waiting list for liver transplantation. There were more infectious complications and/or deaths in a 3-month follow-up period in patients with diabetes mellitus diagnosed by oral glucose tolerance test. Oral glucose tolerance test seems to be indicated as a routine practice in this population.
\end{abstract}

HEADINGS - Diabetes mellitus. Glucose intolerance. Liver cirrhosis. Insulin resistance. Glucose tolerance test. Liver transplantation. Waiting lists.

\section{INTRODUCTION}

The relationship between diabetes mellitus (DM) and cirrhosis has been increasingly discussed. In fact, cirrhotic patients often present alterations in glycemia control. Regarding insulin, most of these patients have reduced depuration, increased peripheral resistance and altered adipocyte sensitivity ${ }^{(30)}$. A great number of patients compensate for insulin resistance (IR) with elevated pancreatic insulin secretion. The results are high levels of circulating insulin, normal fasting glycemia and impaired glucose tolerance (IGT) ${ }^{(17)}$. IR plays an important role in the appearance of metabolic syndrome (MS). Its presence is associated with a higher risk of DM complications, cardiovascular disease $^{(11)}$ and hepatic steatosis ${ }^{(10)}$, and it may cause faster progress of different liver disorders ${ }^{(12)}$.

Some studies report that the prevalence of DM associated with the presence of chronic hepatitis is on average 4 times higher than in the general population, especially due to hepatitis $\mathrm{C}$ virus $(\mathrm{HCV})^{(14)}$.

Currently, chronic infection provoked by $\mathrm{HCV}$ is the main cause of liver transplantation (OLT) in the western world. OLT is a very complex procedure that involves considerable risks, and the presence of DM in a candidate for OLT may negatively affect the pre-OLT clinical evolution and post-OLT long-term survival. In addition, protein calorie malnutrition $(\mathrm{PCM})$ is

'Programa de Pós-Graduação em Gastroenterologia, Universidade Federal do Rio Grande do Sul (UFRGS); ${ }^{2}$ Departamento de Medicina Interna, UFRGS, Porto Alegre RS, Brasil.

Correspondence: Nutr. Ana Carolina Costa Bragança - Rua Jornal do Brasil, 111 - apt. 509 - 90050-050 - Porto Alegre, RS, Brasil. E-mail: carol.bragança@terra.com.br 
frequently found in patients with chronic liver disorders of alcoholic or non-alcoholic origin ${ }^{(2,18,22)}$, promotes poor hepatic evolution, and impacts on OLT results and costs.

The purpose of this study was to determinate the prevalence of glucose metabolism disorders in cirrhotic patients being evaluated for transplantation and their impact during a 3-month follow-up period, focusing on infectious complications and/or death.

The study also aims to compare fasting glycemia and oral glucose tolerance tests (OGTT) in diagnosing DM in this population.

\section{METHODS}

This cross-sectional study was performed on 62 cirrhotic adult patients from both genders on the waiting list for OLT, regardless of the etiology. Patients without the ability to use the dynamometer, either due to cognitive difficulties or neuromuscular alterations in the upper limbs, were excluded, as well as individuals with malignant tumors. Patients presenting with hepatocellular carcinoma, if in accordance with the Milan criteria ${ }^{(21)}$, were not excluded.

Cirrhosis was diagnosed according to histological analysis or clinical criteria, such as the presence of complications like variceal hemorrhage, ascites and/or hepatic encephalopathy and/or imaging and laboratory exams consistent with the diagnosis.

At the time of inclusion, all patients were submitted to blood collection and nutritional assessment. Diagnosis of DM was established through the results of fasting glycemia and OGTT ${ }^{(7,28)}$. OGTT was performed as described by the World Health Organization after and oral anhydroglucose 75 $\mathrm{g}$ load and glycemia measurement at times 0 and 120 minutes.

IR and pancreatic $B$ cell functions were determined by the homeostasis model assessment (HOMA) method, which uses the following equation: HOMA-IR $=\{$ [insulin $(\mathrm{mU} / \mathrm{mL}) \mathrm{x}$ glycemia $(\mathrm{mg} / \mathrm{dL})] / 405\}$ and HOMA- $\beta=\{[20 \mathrm{x}$ insulin $(\mathrm{mU} /$ $\mathrm{mL})] /[$ glycemia $(\mathrm{mmol} / \mathrm{L})] \times 0.00051]-3.5\}^{(16)}$. The presence of IR was considered when the HOMA-IR index was 2.71 or higher ${ }^{(32]}$. The function of pancreatic $B$ cells was considered adequate when HOMA- $\beta=100 \% \%^{(20)}$.

Body Mass Index (BMI) was calculated using the formula proposed by the FAO/WHO committee in 1985 based on weight (in kilograms) divided by squared height (in meters), as follows: $\mathbf{B M I}=$ weight height $^{2}$. For the BMI calculation, weight was estimated subtracting the ascites weight, according to the ascites intensity (mild ascites: $2 \mathrm{~kg}$; moderate ascites: $6 \mathrm{~kg}$; severe ascites: $14 \mathrm{~kg})^{(19)}$.

Nutritional assessment was performed using Subjective Global Assessment (SGA), described by Detzky et al. ${ }^{(8,13,15,24}$, ${ }^{25)}$, anthropometry (weight, height, BMI, triceps skinfold, arm circumference (AC) and arm muscle circumference (AMC) and measurement of non-dominating handgrip strength (HGS) through dynamometry.

The measurement of the triceps skinfold (TSF) was obtained using a Lange Skinfold Calipter ( $\beta$ Technology
Incorporated Cambridge, Maryland, USA) at the mean point between the acromion and the olecranon following the traditionally adopted method. AC was measured using a non-extensible measuring tape with millimeter grading at the same site as the TSF measurement; measurements were recorded in centimeters. All anthropometric measurements were performed 3 times, and the mean value was used. AMC was used to determine muscle mass, defined by Blackbum and Thornton, in $1979^{(9)}$. AMC was calculated using the following formula: $\mathbf{A M C}=\mathbf{A C}-($ TSF $x$ 0.314). HGS measurement used the dynamometry technique ${ }^{(4)}$ and a $1 \mathrm{kgf}$ graded Baseline ${ }^{\circledR}$ dynamometer with a $100 \mathrm{kgf}$ capacity, a clock indicator, and a maximum reading pointer. Three measurements were taken from each patient, and the greatest value was used. The anthropometrical and HGS measurements were compared to tables with normal values for the patient's age and gender ${ }^{(3)}$.

An 8-hour fast was observed in order to perform the biochemical analyses. Plasmatic glucose was determined through the calorimetric enzymatic method. The electrochemiluminescence method was used to determine serum insulin.

The patients were instructed and signed the Informed Consent Form. Patients diagnosed with DM or IGT were directed to specialized treatment.

The descriptive analysis used absolute and relative frequencies for the category variables and mean and standard deviation values for continuous variables. The inferential analysis used Student's $t$-test, analysis of variance (ANOVA) and chi-square test. Fisher's exact test was used to evaluate if there was any association between the categorical variables. Data was analyzed using the SPSS 14.0 application, and the level of significance adopted was $5 \%$.

This study had support from the FIPE (Incentive Fund to Research and Events) of the Hospital de Clínicas de Porto Alegre, RS, Brazil, and from the Ministry of Education CAPES Foundation, Brazil.

\section{RESULTS}

This study involved 80 adult patients with a cirrhosis diagnosis being evaluated for transplantation. Among them, 62 met the inclusion and exclusion criteria, $39(62.9 \%)$ were male and $52(83.9 \%)$ white of European origin. The mean age was 54 years old $( \pm 8.4)$. Chronic $\mathrm{HCV}$ infection was the most frequent cause of cirrhosis in the sample studied -25 patients $(40.3 \%)$. Regarding cirrhosis severity, 50 patients $(80.6 \%)$ were classified as Child-Pugh B and C, and the mean MELD score was $14( \pm 3.29)$.

Complications related to portal hypertension and synthesis (recurrent episodic hepatic encephalopathy, refractory ascites and/or spontaneous bacterial peritonitis) were the most frequent indications of transplantation - 33 patients $(53.2 \%)$. At the time of the examination, 22 patients $(36 \%)$ presented ascites. Table 1 summarizes the demographic and clinical data of the studied population. 
TABLE 1. Demographic and clinical characteristics of the studies patients $(\mathrm{n}=62)$

\begin{tabular}{lc}
\hline Male $(\mathrm{n} / \%)$ & $39(62.9)$ \\
Age-years $(\mu / \mathrm{DP})$ & $54( \pm 8.4)$ \\
Child-Pugh $(\mathrm{n} / \%)$ & $12(19.4)$ \\
A & $50(80.6)$ \\
B/C & $14( \pm 3.29)$ \\
MELD score $(\mu / \mathrm{DP})$ & \\
Cirrhosis etiology $(\mathrm{n} / \%)$ & $25(40.3)$ \\
HCV & $17(27.4)$ \\
HCV + alcohol & $13(21)$ \\
Alcohol & $2(3.3)$ \\
HBV & $1(1.61)$ \\
HBV + alcohol & $1(1.61)$ \\
NAFLD & $3(4.8)$ \\
Others & 3 . \\
\hline MELD = model for end stage liver disease; HCV = heparitis C virus; HBV = hepatitis B virus; NAFLD = nonalcoholic fatty liver disease
\end{tabular}

Forty patients were diagnosed as diabetics $(64.5 \%), 16$ $(25.8 \%)$ patients presented IGT, and only $6(9.67 \%)$ were considered euglycemics. Among patients diagnosed as diabetics, the fasting glycemia test detected DM in $9(22.5 \%)$, and OGTT was able to identify DM in $31(77.5 \%)$. Among the patients identified as diabetic only through the OGTT method, 16 patients $(51.6 \%)$ had no indication for performing an OGTT. Figures 1 and 2 summarize these findings.

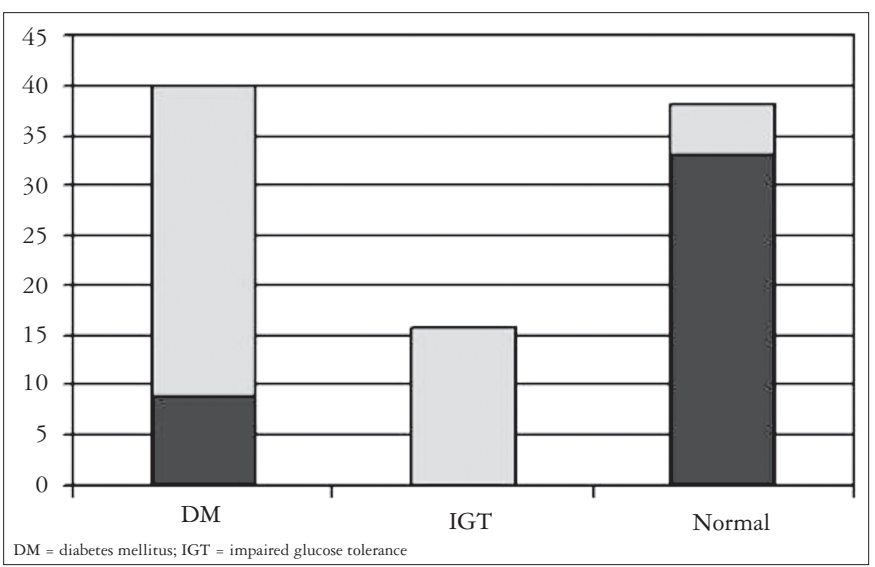

FIGURE 1. Findings related to the glycemic levels $(n=62)$

Evaluating patients with and without $\mathrm{HCV}$, the proportions found were $26.2 \%$ and $25 \%$ of IGT and $69 \%$ and $55 \%$ of $\mathrm{DM}$, respectively. There was no significant difference between those with $\mathrm{HCV}$ and those without $\mathrm{HCV}$.

The prevalence of IR was 69\% (40 patients). Among these patients, 19 patients $(47.5 \%)$ had HCV and 32 patients $(80 \%)$ were Child-Pugh B and C. Among those 40 patients with IR, $27(67.5 \%)$ presented DM. Regarding pancreatic beta cells, $50(86.2 \%)$ of the patients presented abnormal values: 36 of them $(72 \%)$ presented an increased function.

PCM was found in 2 patients $(3.22 \%)$ through BMI; in 9 patients (14.5\%) through TSF; in $20(32.3 \%)$ through AC; in $28(45.2 \%)$ through AMC; in $36(58.1 \%)$ through SGA and in $55(88.7 \%)$ through the HGS. Among the $55(88.7 \%)$ patients

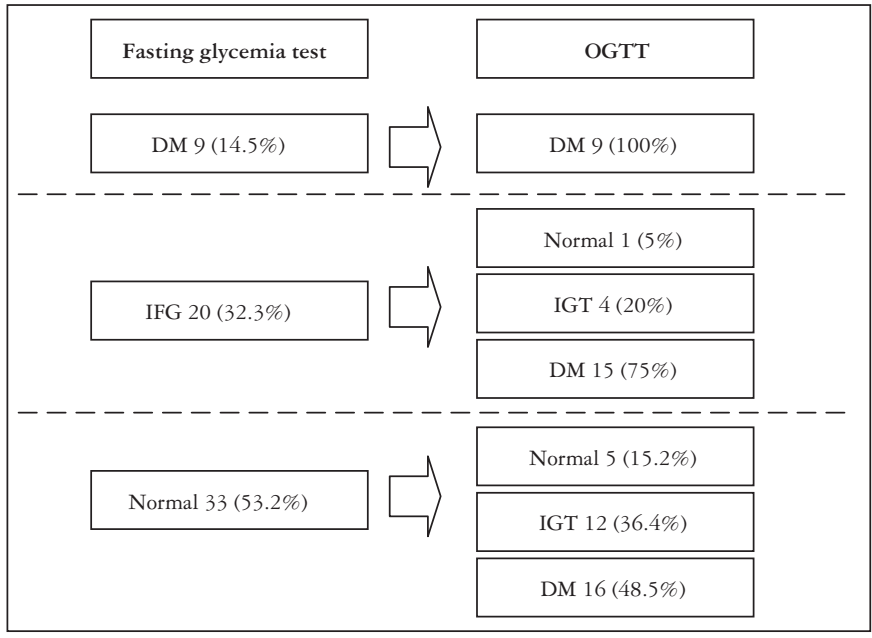

OGTT = oral glucose tolerance test; DM = diabetes mellitus;

IFG = impaired fasting glucose; IGT $=$ impaired glucose tolerance

FIGURE 2. Obtained findings with fasting glycemia test and oral glucose tolerance test in the studied patients $(n=62)$

identified as malnourished through the HGS, 47 (85.5\%) patients were Child-Pugh B and C. There was a correlation between disease severity and malnutrition measured through the HGS $(P=0.022)$.

Considering the 9 patients who, through the fasting glycemia test, were considered as diabetic, 8 were Child-Pugh B and $\mathrm{C}$, and among the 31 patients considered diabetic through OGTT, 26 patients ( $76.5 \%$ ) were Child-Pugh B and C. There was no correlation between the presence of diabetes and cirrhosis severity ( $P=0.675$ and 0.317 , respectively). Among the patients diagnosed as diabetic through OGTT, 17 patients $(54.8 \%)$ presented MELD score of 15 or above. There was also no association between the presence of diabetes detected through OGTT and cirrhosis severity assessed through MELD score $(P=0.451)$.

Regarding the 3-month evolution of patients after the initial evaluation, $12(19,4 \%)$ of them presented infectious bacterial complications (acute gastroenteritis, bronchopneumonia, urinary tract infection, skin infection and/or spontaneous bacterial peritonitis), $12(19.4 \%)$ of them died, and $3(4.8 \%)$ patients received a liver transplant. Considering patients with DM diagnosis through OGTT, the proportion who had infectious complications and died within 3 months was $52.6 \%$ (20 patients), and the percentage that were considered normal was 19\% (4 patients). There was a correlation between the presence of diabetes diagnosed by OGTT and the presence of complications and death within 3 months after the evaluation $(P=0.017)$. The same was not true when considering DM diagnosed by fasting glucose $(P=0.16)$. Table 2 summarize these findings.

Considering that the MELD score predicts mortality within 3 months, the association between the MELD score and the presence or not of DM and the impact on mortality was tested, but no association was found.

A ROC curve was constructed in order to identify the best cut-off of fasting glucose to diagnose DM in this population. 
TABLE 2. Incidence of infectious complications and deaths in the 3-month follow-up in the studied patients, accordingly to glycemic status

\begin{tabular}{lcc}
\hline Glycemic status & $\begin{array}{c}\text { Bacterial complications } \\
\text { and deaths }(\mathrm{n}=24)\end{array}$ & $\boldsymbol{P}$ \\
\hline DM diagnosed by OGTT $(\mathrm{n}=40)$ & $50 \%(20)$ & 0.017 \\
DM diagnosed by fasting glycemia $(\mathrm{n}=9)$ & $55.5 \%(5)$ & 0.16 \\
Euglycemics $(\mathrm{n}=6)$ & $16.6 \%(1)$ & $>0.05$ \\
\hline
\end{tabular}

DM $=$ diabetes mellitus; OGTT $=$ oral glucose tolerance test

The determined cut-off point was $\geq 94 \mathrm{mg} / \mathrm{dL}$ (sensitivity $=$ 0.65 ; specificity $=0.68)$. In accordance with this method, DM was diagnosed in 23 patients $(37.1 \%)$.

\section{DISCUSSION}

Cirrhotic patients are at risk for developing DM, mainly those with HCV. This study analyzed the prevalence of DM and IGT in cirrhotic patients in late stages of the disease. As the presence of DM is a prognostic factor for long-term survival of liver-transplanted patients, a comprehensive diagnostic approach is essential. However, in a search of PubMed using the terms "diabetes", "cirrhosis", "liver transplantation" and "waiting list", only four papers were found (one of them prospective, DM being diagnosed through fasting glycemia $\left.{ }^{(27)}\right)$. If we change "diabetes" to "impaired glucose tolerance", it is even worse: no papers were found. This seems clearly insufficient and may indicate a lack of interest on this issue. Our question is: is it an unimportant issue? Are all the questions already answered?

When evaluating cirrhotic candidates for OLT through fasting glycemia and OGTT methods, this study found an elevated prevalence of IGT and a greater prevalence of DM. These prevalences were greater than those described in other studies focusing liver transplant candidates ${ }^{(27,34]}$ and compensated cirrhotics ${ }^{(26)}$. This higher prevalence may be related to the use of OGTT, and may also be because our patients had a more severe disease. This finding agrees with Custro et al. ${ }^{(14)}$, who associated abnormal glucose metabolism with liver disease severity. Even in cirrhotic patients, the abnormal capability of the glycemic metabolism would be related to disease severity ${ }^{(6)}$.

There was no relationship between HCV and DM. These results were similar to those of a study conducted in Brazil (27) that did not show any difference in the prevalence of DM in cirrhotic candidates for transplantation with or without $\mathrm{HCV}$. Another study showed the same prevalence of DM in cirrhotic patients with $\mathrm{HCV}$ when compared to patients with cirrhosis of alcoholic origin $-25 \%$ and $19 \%$, respectively ${ }^{(34)}$. Considering that chronic hepatitis secondary to HCV and
DM are classically related, we hypothesized that cirrhosis makes this influence disappear.

In normal individuals, $80 \%$ of the glucose production after one night of fasting is a result of glycogenolysis. In cirrhotic patients, the hepatic glycogen reserve is reduced, which affects glycogenolysis. Other substrates are prematurely utilized in glycemia maintenance, such as the mobilization of lipids and amino acids, but it does not prevent reduced glycemia levels after night fasting ${ }^{(23)}$. Perhaps this fact explains the poor performance of fasting glycemia for DM diagnosis in this population.

OGTT was universally performed in our study, and this may partly explain the prevalence found. We think that this test must be considered in this population. In fact, an ADA follow-up report in 2003 showed that both fasting glycemia and OGTT can be used for diagnosing $\mathrm{DM}^{(31)}$. Nevertheless, OGTT is not very practical, and it is also more likely to diagnose DM in lean subjects ${ }^{(33)}$, as cirrhotics usually are.

In accordance with the ROC curve constructed, the best cutoff for DM diagnosis in this population was 94. It must be emphasized that both sensitivity and specificity are low, reinforcing the idea that this issue deserves more study.

It is believed that both insulin resistance and impaired insulin pancreatic secretion can be the DM subjacent mechanism in cirrhotic patients ${ }^{(1)}$. The prevalence of IR in this study was high. Pancreatic beta cell function was impaired in most of the patients. There is insufficient data published that can be compared to our results.

Regarding nutritional states, this study demonstrated a high PCM prevalence, especially through HGS. Other studies have shown this method to be the most sensitive method for PCM diagnosis in such a population ${ }^{(1,4,5,6,29)}$.

During the 3-month follow-up period, diabetic cirrhotic patients presented more infectious complications and/or deaths than non-diabetics. There was a relationship only when DM diagnosis was made by OGTT.

In conclusion, the prevalences of DM, IGT and IR are high in cirrhotic patients on the waiting list for OLT and should be routinely evaluated in such patients, as infectious complications and death within 3 months were more common with the presence of DM. OGTT is recommended as a routine practice for this population.

\section{ACKNOWLEDGEMENTS}

This study had support from the FIPE (Incentive Fund to Research and Events) of the Hospital de Clínicas de Porto Alegre and from the Ministry of Education - CAPES (Foundation Brazil). 
Bragança ACC, Álvares-da-Silva MR. Prevalence of diabetes mellitus and impaired glucose tolerance in patients with decompensated cirrhosis being evaluated for liver transplantation: the utility of oral glucose tolerance test

Bragança ACC, Álvares-da-Silva MR. Prevalência de diabetes mellitus e intolerância à glicose em pacientes com cirrose descompensada em avaliação para transplante hepático: a utilidade do teste oral de tolerância à glicose. Arq Gastroenterol. 2010;47(1):22-7.

RESUMO - Contexto - Cirrose, diabetes mellitus, intolerância à glicose e resistência insulínica é uma associação que vem sendo discutida, bem como a desnutrição nesta população, pelo risco de pior evolução de hepatopatia. Objetivo - Determinar a prevalência de diabetes mellitus, intolerância à glicose e resistência insulínica e desnutrição protéico-calórica em cirróticos (vírus $\mathrm{C}^{+}$ou ) candidatos a transplante hepático e avaliar a capacidade diagnóstica dos testes de diabetes mellitus e seu impacto na evolução em 3 meses. Métodos - Estudo transversal prospectivo de pacientes consecutivos, com avaliação de diabetes mellitus por glicemia de jejum e/ou teste de tolerância oral à glicose, cálculo dos índices HOMA-IR e avaliação nutricional através da avaliação subjetiva global, antropometria e força do aperto de mão não-dominante. Resultados - Sessenta e quatro virgula cinco por cento tinham diabetes mellitus, $9(22,5 \%)$ deles foram diagnosticados por glicemia de jejum e $31(77,5 \%)$ por tolerância oral à glicose. A resistência insulínica foi encontrada em 40 pacientes (69\%). Não houve relação com a causa da cirrose. A desnutrição protéico-calórica foi encontrada em $3,22 \%$ dos pacientes através do índice de massa corporal, $45,2 \%$ por antropometria, $58,1 \%$ pela avaliação subjetiva global e $88,7 \%$ pela força do aperto de mão não-dominante. Houve associação entre diabetes mellitus diagnosticado pelo teste de tolerância oral à glicose e a maior prevalência de complicações infecciosas e/ou morte em 3 meses $(P=0,017)$. Conclusão - A prevalência de diabetes mellitus, intolerância à glicose, resistência insulínica e desnutrição protéico-calórica é alta em cirróticos em lista de transplante hepático. A evolução em 3 meses é pior quando há diabetes mellitus. O teste de tolerância oral à glicose teve rendimento superior à glicemia de jejum no diagnóstico de diabetes mellitus. Sugere-se o emprego rotineiro de teste de tolerância oral à glicose nesta população.

DESCRITORES - Diabetes mellitus. Intolerância à glucose. Cirrose hepática. Resistência à insulina. Teste de tolerância à glucose. Transplante de fígado. Listas de espera.

\section{REFERENCES}

1. Álvares-da-Silva MR. Comparação entre a avaliação nutricional subjetiva global, índice prognóstico e força do aperto de mão não-dominante na avaliação nutricional do paciente cirrótico ambulatorial: a contribuição da dinamometria [dissertação]. Porto Alegre: Faculdade de Medicina da Universidade Federal do Rio Grande do Sul; 1995.

2. Álvares-da-Silva MR, Gottschall CA, Pruineli RD, Waechter FL, Cardoso F, Sampaio JA, Smith MM, Francisconi CFM, Pereira-Lima LM. Nutritional evaluation in liver transplantation. Hepatology. 1998;28:746(A).

3. Álvares-da-Silva MR, Silveira TR. Non-dominant handgrip strength study in healthy individuals. Determinations of reference values to be used in dynamometry. GED Gastroenterol Endosc Dig. 1998;17:203-6.

4. Álvares-da-Silva MR, Gottschall CA, Waechter FL, Hadlich E, Sampaio JA, Francesconi CF. O uso da nutrição enteral precoce pós-transplante hepático adulto. Arq Gastroenterol. 2004;41:147-9.

5. Álvares-da-Silva MR, Silveira TR. Comparison between handgrip strength, subjective global assessment, and prognostic nutritional index in assessing malnutrition and predicting clinical outcome in cirrhotic outpatients. Nutrition. 2005;21:113-7.

6. Álvares-da-Silva MR, Silveira TR. Hand-grip strength or muscle mass in cirrhotic patients: who is the best? Nutrition. 2006;22:218-9.

7. American Diabetes Association. Standards of medical care in diabetes. Diabetes Care. 2005;28(suppl 1):s4-s36.

8. Baker JP, Detsky AS, Wesson DE, Wolman SL, Stewart S, Whitewell J, Langer B, Jeejeebhoy KN. Nutritional assessment: a comparison of clinical judgment and objective measurements. N Engl J Med. 1982;306:969-72.

9. Blackburn GL, Thornton PA. Nutritional assessment of the hospitalized patients. Med Clin North Am. 1979;63:1103-15.

10. Caldwell SH, Ikura Y, Iezzoni JC, Liu Z. Has natural selection in human populations produced two types of metabolic syndrome (with and without fatty liver?) J Gastroenterol Hepatol. 2007;22:s11-s9.

11. Castro SH, Matos HJ, Gomes MB. Parâmetros antropométricos e síndrome metabólica em diabetes tipo 2. Arq Bras Endocrinol Metab. 2006;50:450-5.

12. Chang CY, Argo CK, Al-Osaimi AM, Caldwell SH. Therapy of NAFLD: antioxidants and cytoprotective agents. J Clin Gastroenterol. 2006;40:s51-s60.

13. Coppini LZ, Waitzberg DL, Ferrini MT, Silva MLT, Gama-Rodrigues J, Ciosak SL. Comparação da avaliação nutricional subjetiva global $\mathrm{x}$ avaliação nutricional objetiva. Rev Assoc Med Bras. 1995;41:6-10.

14. Custro N, Carroccio A, Ganci A, Scafidi V, Campagna P, Di Prima L, Montalto G. Glycemic homeostasis in chronic viral hepatitis and liver cirrhosis. Diabetes Metab (Paris). 2001;27:476-81.
15. Detsky AS, McLaughlin JR, Baker JP, Johnston N, Whittaker S, Mendelson RA, Jeejeebhoy KN. What is subjective global assessment of nutritional states? JPEN J Parenter Enteral Nutr. 1987;11:8-13.

16. Geloneze B, Tambascia MA. Avaliação laboratorial e diagnóstico da resistência insulínica. Arq Bras Endocrinol Metab. 2006;50:208-15.

17. Gitzelmann R, Spycher MA, Feil G, Mülle J, Seilnacht B, Stahl M, Bosshard NU. Liver glycogen synthase deficiency a rarely diagnosed entity. Eur J Pediatr. 1996;155:561-67.

18. Gottschall CA, Álvares-da-Silva MR, Camargo AC, Burtett RM, Silveira TR. Avaliação nutricional de pacientes com cirrose pelo vírus da hepatite $C$ : a aplicação da calorimetria indireta. Arq Gastroenterol. 2004:41:220-4.

19. James R. Nutritional support alcoholic liver disease: a review. J Human Nutr. 1998;2:315-23

20. Mathews D, Hosker JP, Rdenski AS, Naylor BA, Trecher DF, Turner RC Homeostasis model assessment: insulin resistance and B-cell function from fasting plasma glucose and insulin concentration in man. Diabetologia. 1985;28:412-9.

21. Mazzaferro V, Regalia E, Doci R, Andreola S, Pulvirenti A, Bozzeti F, Montalto F, Ammatuna M, Morabito A, Gennari L. Liver transplantation for the treatment of small hepatocellular carcinomas in patients with cirrhosis. N Engl J Med. 1996;334:693-9.

22. McCullough AJ. Malnutrition in liver disease. Liver Transpl. 2000;6:s85-S96.

23. Morgan MY. Nutritional aspects of liver and biliary disease. In: Mc Intyre N, Benhamou JP, Bircher J, Rizzeto M, Rodès J, editors. Oxford Textbook of Clinical Hepatology. Oxford: Oxford University Press; 1991. p.1339-87.

24. Morgan MY, Madden AM, Jennings G, Elia M, Fuller NJ. Two-component models are of limited value for the assessment of body composition in patients with cirrhosis. Am J Clin Nutr. 2006;84:1151-62.

25. Morgan MY, Madden AM, Soulsby CT, Morris RW. Derivation and validation of a new global method for assessing nutritional status in patients with cirrhosis Hepatology. 2006:44:823-35.

26. Nishida T, Tsuji S, Tsujii M, Arimitsu S, Haruna Y, Imano E, Suzuki M, Kanda T, Kawano S, Hiramatsu N, Hayashi N, Hori M. Oral glucose tolerance test predicts prognosis of patients with liver cirrhosis. Am J Gastroenterol. 2006;101:70-5.

27. Parolin MB, Zaina FE, Araújo MV, Kupka E, Coelho JCU. Prevalence of type 2 diabetes mellitus in Brazilian liver transplant candidates: Negative association with HCV status. Transpl Proc. 2008;36:2774-5.

28. Report of the Expert Committee on the Diagnosis and Classification of Diabetes Mellitus. Diabetes Care. 1997;20:1183-97.

29. Ritter L, Gazzola J. Avaliação nutricional no paciente cirrótico: uma abordagem objetiva, subjetiva ou multicomportamental? Arq Gastroenterol. 2006;43:66-70.

30. Shen J, Bao Y, Liu HM, Lee P, Leonard JV, Chen YT. Mutations in exon 3 of the glycogen debranching enzyme gene are associated with glycogen storage 
disease type III that is differentially expressed in liver and muscle. J Clin Invest. 1996;98:352-7.

31. Standards of medical care in diabetes 2007. Diabetes Care. 2007; 30(suppl 1): s4-s41.

32. Wallace TM, Levy JC, Matthews DR. Use and abuse of HOMA modeling. Diabetes Care. 2004;27:1487-95.

33. Will new diagnostic criteria of diabetes mellitus change phenotype of patient with diabetes? Reanalysis of European epidemiological data. DECODE Study
Group on behalf of the European Diabetes Epidemiology Study Group. BMJ. 1998;317:371-5.

34. Zein NN, Abdulkarim AS, Wiesner RH, Egan KS, Persing DH. Prevalence of diabetes mellitus in patients with end-stage liver cirrhosis due to hepatitis $\mathrm{C}$, alcohol or cholestatic disease. J Hepatol. 2000;32:209-17.

Received 3/12/2008 Accepted 23/6/2009. 